\title{
The problem of the development of foreign language professional competencies of public administration students
}

\author{
Guliya Nurlybaeva ${ }^{1 *}$ \\ ${ }^{1}$ Russian Presidential Academy of National Economy and Public Administration (RANEPA), \\ prospekt Vernadskogo, 82, Moscow, 119571 Moscow, Russian Federation
}

\begin{abstract}
For the full realization of the strategic goals of public administration, as well as the worthy representation of the interests of the state at the international level, public servants must have high foreign language professional competencies. This is stated in the Concept of Sustainable Development until 2030, adopted by the UN in 2015, as well as in the Strategy for the Innovative Development of Russia until 2020, prepared by the Ministry of Economic Development of the Russian Federation. The author analyzed the current state of the level of foreign language training of the students at the Institute of Social Sciences (ISS) of the Academy of National Economy and Public Administration under the President of Russia (RANEPA) basing on a study of the practice of creating training programs for the development of foreign-language professional competencies of future public servants. The analysis included the identification of existing tasks, goals, learning technologies that could meet the qualification requirements of future public servants, the identification of ways to develop foreign-language competencies of students, the ways of improvement of methodological support for the teaching of foreign languages, the principles of using textbooks to solve the above-mentioned problems. The methodology of the study included the methodology of theoretical, analytical, empirical research (the questionnaire and the survey of 80 students of ISS, RANEPA) as well as a comparative research methodology. Some conclusions were made based on the results obtained, and the ways to improve programs for formation and development of foreign-language professional competencies of future public servants were outlined by the author. Some recommendations for teachers and education managers are given. The results of the study could help foreign language teachers create an effective learning environment for future public servants.
\end{abstract}

\section{Introduction}

Public policy in the field of education and training of public servants in all countries of the world is connected with the problems relating the general goals and objectives of the public service. In the twenty-first century - the century of internationalization of the economy and global challenges to humanity - it became clear that in order to achieve the strategic goals of public administration, as well as to represent the interests of the state at the international level adequately, public servants must have high foreign-language professional

* Corresponding author: nurlybaeva-gk@ ranepa.ru 
competencies. The fact that state servants should have high foreign-language professional competencies is emphasized at a number of international and Russian documents: the Strategy of Sustainable Development until $2030^{1}$, The Strategy for the Innovative Development of Russia until 2020, prepared by the Ministry of Economic Development of the Russian Federation. It says: "The qualification requirements for those holding public service positions of the senior and highest groups should include foreign language competencies at a level that allows direct communication with foreign colleagues." 2 It follows from this statement that the problem of the development of foreign-language competencies of future public servants in the current time has become especially urgent.

Scientists studying public service in Russia and abroad have also repeatedly emphasized the importance of improving the foreign-language competencies of future public servants. Veronica Kareva [Kareva, 2013, pp.1477 - 1481] wrote: "Public sector institutions, such as various government bodies, ministries, local authorities, state enterprises, courts and public organizations, need public servants with good communication skills in English to communicate with the international community and representatives of international organizations on topics related to public administration and politics." Thus, the process of formation and development of foreign-language professional competencies among students studying in the specialty "public administration" requires careful research and improvement.

The purpose of our research was to analyze the current state of the level of language training of future civil servants - the students, undergraduates and graduate students - to identify and set the tasks and goals to improve the quality of their proficiency in foreign language ( in our case - English). The contribution of the author to the creation and development of methodical basis for the students studying public service will make it possible to raise the quality of their future level of foreign language competencies. This study can also be useful for establishing and improving qualification requirements for civil servants, improving the methodological support for foreign language education in universities that train public servants, creating textbooks and teaching aids to solve the above problems. Improvement of the process of the development of foreign-language professional competencies of students studying in the specialty "public administration" will also improve the quality of foreign language training of public servants in accordance with new qualification requirements.

The theme "Formation and development of foreign-language professional competencies of students studying in "public administration" specialty" was considered in the educational and methodological manuals of E.V. Abramova, C. Connoly Knox, J.V. Dmitrieva, V. Kareva, O. B. Koretskaya, A.G. Krasyuk, O.N. Kastornova, I.B. Korotkina, G.Nurlybaeva, etc. This problem, however, has not been fully developed and requires significant refinement taking into account the modern requirements of the Concept of Sustainable Development until 2030, adopted by the UN in 2015. The object of the study are students, undergraduates and graduate students - future civil servants studying at the Institute of Social Sciences (ISS) RANEPA, Moscow. The research methods used included the analysis of literature and theoretical studies on the problem considered, the analytical research methods, the methodology of empirical research, the methods of comparative research, etc.

\footnotetext{
${ }^{1}$ The Strategy of Sustainable Development till 2030, adopted by UNO in 2015

${ }^{2}$ The Strategy of Innovative Development of Russia until 2020
} 


\title{
2 Theory and practice of the development of foreign- language professional competencies of public administration students
}

\subsection{The necessity of practical approach to the creation of the programs of English language teaching at the universities for future public servants}

\begin{abstract}
After analyzing the literature on the problem, we identified the main goals and scope of the study, as well as the methods that we should use during it. It was concluded that the use of foreign language textbooks containing only information about the history of public administration in different countries, the theoretical problems of public administration functioning at different times, as well as the discussion of the problems of using business English in classes are not sufficient to solve modern problems of public administration. There is a gap between the real practical needs of public servants in the field of their proficiency in foreign languages and teaching foreign languages at the faculties of public administration at universities. In our opinion, teaching English for Special Purposes (ESP) and the development of foreign-language competencies of students in the faculties of public administration require special attention and a more practical approach. ESP programs should not include only general information about public service, as it is often the case now. Foreign language programmes at the university should be created specifically for future public servants. While language programmes may also include some general theoretical and historical information on public service, programmes should not be limited to such information and should take into account the practical needs of future public servants. A practical approach to creating new programs should be applied when during classes it is necessary, first of all, to develop the communication skills of students among other foreign-language competencies.
\end{abstract}

\subsection{The analysis of the development of foreign-language competencies of the future public administration servants at the ISS of RANEPA}

The paper describes some aspects of the author's development of foreign-language competencies of students. It also contains the description of practical measures taken in the field of development of foreign language competencies at the Institute of Social Sciences (ISS) RANEPA, Moscow, during the 2018/2019 academic year. Certain conclusions were drawn that, in our opinion, could help university teachers working in the field of education in the field of public administration to improve both the process of teaching a foreign language and its results.

The foreign-language professional competencies are based on the integration of four language areas: listening, speaking, reading and writing [Dual Language Professional Competencies. 2013]. It is assumed that students will possess all this competencies by the time they receive their diploma. The set of foreign-language competencies refers to the principles of training of students, to their academic results, as well as to the creation of professional readiness of students for their future activities. At the end of their studies, students must demonstrate all the above-mentioned competencies which could allow them to successfully work in the field of public service. The English Language Department of the Institute of Social Sciences of the RANEPA, Moscow, compiled tables of evaluation criteria and degrees of formation and development of foreign language competencies for undergraduate students and presented English language programs for the period of four years of study. For each English language learning stage, evaluation criteria have been presented. 
The analysis of the needs of students showed that more attention should be paid to the development of such communication skills of students as listening, speaking and writing. The final exams of students at the ISS RANEPA, Moscow, also included such parts of study as "Social and Political Vocabulary," online courses with specific professional vocabulary, Project Design (for the 3rd year of study). Such factors as attendance, participation in work during classes, etc., also contributed to the final assessment of each student's performance.

We analyzed the work of the ISS RANEPA students during the first and second semesters of 2018/2019 in four student groups of the Liberal Arts direction (80 students) and found that some progress has been made during the year in which the new approach to learning had been applied.

\subsection{The actual professional vocabulary is the main thing necessary for effective communication of civil servants}

You can read the following words in Public Administration Education journal "Administrators not only need to know about communications, they need to be able to communicate."[Connolly Knox, 2013, pp. 515-536]. The first thing that is necessary for effective communication and understanding is common professional vocabulary of public servants. Therefore, teaching the students foreign-language professional vocabulary is so important in the training of future public servants.

The course "Social and Political Vocabulary" introduced at the ISS RANEPA, Moscow, should partially fulfill these tasks, and lexical analysis of this course may be in future included in the "International English Dictionary in the Field of Public Administration" as a part of it. The author believes that this course should be improved and expanded during the years of study, taking into account a thorough analysis of the needs and goals of the students.

Such forms of teaching a foreign language as collective problem solving, group discussions would be of great help in mastering the communication skills of students. The main purpose of all these forms of education is to encourage students to speak freely on a particular topic when setting clear communicative tasks. The "problem solving" method requires students to formulate and propose solutions using vocabulary and terms specific to a particular discipline. This method helps students to understand the proposed ideas, ask questions and answer them, put forward their own ideas and explain their thinking process. During the application of the "problem solving" method such language competencies as reading and writing are also developed. This method can be combined with teamwork, which develops language skills such as listening and speaking in the first place. Teamwork also contributes to the development of skills such as reading and understanding professional texts, the ability to select the necessary information from a wide variety of sources containing both written texts and visual information.

\subsection{The use of modern technologies of foreign language teaching for the development of foreign-language competencies of future public servants}

As it was already mentioned, in order the civil servants were fully proficient in foreign language four areas (listening, speaking, reading and writing), their skills need to be developed in accordance with modern foreign language teaching technologies. Among them are such innovative methods and technologies: E-learning, modular training technologies, role-playing games, collective problem solving, group discussions, etc. Training programs on various profiles should be developed in collaboration with teachers 
of specialized disciplines. In addition, foreign language teachers should allow students to use special computer programs. This is especially important when using distance learning, which is becoming more and more involved in the practice of teaching a foreign language in connection with the challenges of the coronavirus pandemic.

As the study found, one of the most effective ways to develop language competencies is the "case study" method. In this case, students acquire all the above-mentioned competencies by carefully studying specific materials from good practices of public administration. As the researcher Veronica Kareva says [Kareva, 2013, pp.1477 - 1481] teachers should create an effective learning environment using specific terminology in case studies. Students should use a professional foreign language aimed at a specific audience, which will allow them during their future professional career not only to communicate with the appropriate audience, but also to create and provide citizens with competently written documents. To do this, graduates of faculties and departments of public administration must have good writing skills aimed at the audience, as well as understand the discourse of the government and the non-profit sector of public administration.

\subsection{The use of E-learning technologies and digital technologies of teaching public administration students a foreign language}

The use of e-learning technologies and digital technologies in teaching students a foreign language helps them to get the necessary information, solve professional problems, draw up projects, communicate with each other on current topics, do homework, etc. In addition, it will help future public servants gain the necessary skills for real work, because digital communications are becoming increasingly popular in the work of the public service and in its work with citizens.

Students will receive good practice for their future work by participating in online courses offered by teachers during the training of students in a professional foreign language. The introduction of online courses in the process of teaching English at the ISS of RANEPA, Moscow, as an additional method of teaching, can be considered as a new direction for the development of foreign language competencies. Online courses are included in the general E-learning process at the Academy in general and at the ISS, in particular. This form of work was applied by the ISS of RANEPA, Moscow, in 2018/2019, and it is constantly being improved and supplemented. Online courses are created for such areas of study at the ISS as Liberal Arts, Psychology, Management, Political Science and some others.

Another important task is to adapt the students to E-learning at the university and facilitate the learning process for them. Students use technology tools and digital media related to their learning discipline to process and solve problems, to manage projects, and communicate with teachers during training. The results of the student's work in the online environment are taken into account when evaluating his or her work during the final exams, so students should pay special attention to E-learning in general and working with online courses, in particular.

Such form of the development of students' foreign-language competencies as Project Design, which is widely used in the ISS during the third and fourth courses, should be also mentioned. The creation of a project helps students to develop their competencies in several areas: Project Design develops their creative skills and special competencies on the topic being studied, it helps them in the development of their research and communication skills, and, of course, it helps students in the development of their foreign-language competencies, since in most cases the projects should be written in English. Students report on the results of their research at student conferences, presenting their projects. 


\section{Conclusion}

Our study showed that the development of foreign-language competencies and the practically oriented study of professional English at the ISS of RANEPA, Moscow, allowed the students to get closer to achieving real goals of public administration, and to fulfill their professional tasks after graduating from the Academy much better. All new parts of the programmes are included in the evaluation procedure during the final examinations, and the results of the examinations demonstrated the degree of readiness of the students to use English for communication with each other and with citizens while continuing to work as public servants. At the faculties of public administration and foreign language faculties of universities further work should be carried out to form and develop foreign-language competencies of students, and we hope that our research will help foreign language teachers create an effective educational environment for future civil servants.

\section{Acknowledgments}

This paper was financially supported by the Russian Foundation for Basic Research, grant No. 20-012-22046.

\section{References}

1. The Concept of Sustainable Development until 2030, adopted by UNO in 2015. URL: https://www.un.org/sustainable development/development-agenda/ (Access: 24.10.2020)

2. Dual Language Professional Competencies. Performance Outcomes and Performance Indicators $\subset$ Discipline-Based Dual Language Immersion Model AGMUS Ventures, Inc. 2013@ December 16, 2013 (2013) URL: https://www.bilingualonline.net/.../DL_Professional_Competencies.pdf 24.10.2020)

(Access:

3. Kareva Veronika. English for Specific Purposes: Public Administration and Political Sciences Procedia - Social and Behavioral Sciences 70 ( 2013 ) pp.1477 - 1481(2013)

4. C. Connoly Knox. Teaching Grammar and Editing in Public Administration: Lessons Learned from Early Offerings of an Undergraduate Administrative Writing Course. JPAE 19 (3), 515-536 (2013)

5. The Strategy of Innovative Development of Russia until 2020 URL: https://cyberleninka.ru/article/n/strategiya-innovatsionnogo-razvitiya-rossiyskoyfederatsii-na-period-do-2020-goda-otsenka-adekvatnosti-trebovaniyam-vremeni (Access: 24.10.2020)

6. Korotkina I. B. English for Public Policy, Administration and Management. M: Yurayt, 2017. - 229 S. (2017) (in Russ.)

7. Krupchenko, A. K. Foreign language education in the context of globalization and internationalization / A. K. Krupchenko / / European Social Science Journal, 2014, No. 9, volume 1. (2014) (in Russ.)

8. Nurlybaeva G. K. The System of Graduate Programs of London Metropolitan University (UK): the State and Municipal Management Program: analytical materials. M.: The Academy of Management of the Ministry of the Interior of Russia, 2014. Page 51 (2014) (in Russ.) 